\title{
The Use of Human Resources Practices and Employee Attitudes: The Linked Personnel Panel
}

\author{
Patrick Kampkötter (University of Cologne) \\ Jens Mohrenweiser (Bournemouth University) \\ Dirk Sliwka (University of Cologne, IZA, and CESifo) \\ Susanne Steffes (ZEW Mannheim) \\ Stefanie Wolter (IAB Nuremberg)
}

\begin{abstract}
This paper introduces a new data source available for HRM researchers and personnel economists, the Linked Personnel Panel (LPP). The LPP is a longitudinal and representative employer-employee data set designed for quantitative empirical HR research. The LPP offers a unique structure. First, the data set combines employer and employee surveys that can be matched to each other. Second, it can also be linked to a number of additional administrative data sets. Third, the LPP covers a wide range of firms and workers from different backgrounds. Finally, because of its longitudinal dimension, the LPP should facilitate the study of causal effects of HR practices. The LPP employee survey uses a number of established scales to measure job characteristics, personal characteristics, and employee attitudes. This paper gives an overview of both the employer and employee survey and additionally outlines the definitions, origins and statistical properties of the items used in the individual questionnaire.
\end{abstract}

Keywords: HR practices; matched employer-employee data; Linked Personnel Panel; employee attitudes

Acknowledgements: We thank for financial support through the project "Quality of Work and Economic Success: Longitudinal Study in German Establishments" (Arbeitsqualität und wirtschaftlicher Erfolg: Längsschnittstudie in deutschen Betrieben) which is funded by the Federal Ministry of Labour and Social Affairs (BMAS) and the Institute for Employment Research (IAB). We also thank infas (Institute for Applied Social Sciences) and TNS Infratest for excellent data collection and support. 


\section{Introduction}

One of the key interests of human resources management (HRM) researchers and personnel economists is to study the use and usefulness of HRM practices, taking into account the variety of contexts in which firms operate. Such evidence-based HR management requires detailed information about the status quo of practices used in firms, which is often collected through firm-level surveys. In management research, scholars have already for quite some time studied the connection between the use of so-called high performance work practices, i.e. combinations or bundles of human resource (HR) management practices, and employee attitudes and firm performance, typically with quite mixed results (for example, Huselid, 1995; Combs et al., 2006; Subramony, 2009). More recently, economists have also started to conduct large-scale survey studies to investigate the connection between management practices and firm performance (Bloom and van Reenen, 2007, 2010). However, due to the mainly cross-sectional nature of the used data sets, these studies typically cannot establish causal effects. Moreover, these studies frequently use firm-level data, which often does not permit the identification of channels through which changes in HR practices affect employee attitudes and behaviour.

In order to facilitate the identification of causal effects, a longitudinal dimension is of substantial importance to track changes in the use of these practices over time. As HR practices aim at affecting firm performance by changing employees' attitudes and behaviour, an analysis of their impact should ideally also take both the employer and employee perspectives into account.

This article introduces a new data set that meets these requirements: the Linked Personnel Panel (LPP). The LPP is a longitudinal linked employer-employee survey [1] that is representative for German private sector establishments with 50 or more employees. The LPP links employer-level information about HR policies with employee-level information about attitudes and behaviour, enabling researchers to analyse how individuals perceive their work and how they respond to HR policies. The longitudinal dimension of the LPP further facilitates the analysis of causal effects of HR policies on various outcome measures by eliminating time-constant unobserved variables.

This article introduces the design and sampling of the first wave of the employer and employee survey. It describes in detail the definitions, origins, and the statistical properties of the survey items used to assess job and personal characteristics, as well as attitudes and behavioural variables in the employee survey.

For the employer survey, managers of 1,219 establishments provided detailed information about a broad variety of HRM practices and a number of firm characteristics. For the employee survey, a total 
of 7,508 employees working in these establishments were interviewed via telephone about job characteristics and job perceptions, personal characteristics, attitudes towards their organisation and behavioural variables. A unique feature is the possibility to link both dimensions of the LPP to various external administrative data sets and enrich the available information across a number of dimensions.

The employee survey adapts a number of items from well-established scales widely used in the literature. The measures incorporate job characteristics and perceptions such as work design, supervisory support, perceived fairness, clarity of organizational goals, reward structure, and workfamily and family-work conflicts. Personal characteristics comprise personality (Big Five), risk attitude, trust and a number of socio-demographic variables. Attitudes include work engagement, affective commitment and job satisfaction. Behavioural variables comprise turnover intention, sickness absence, and, in later waves, real turnover.

\section{Construction of the LPP Data Sets}

This section briefly describes the sampling and construction of the Linked Personnel Panel (LPP). The LPP was created in response to an enquiry of the German Federal Ministry of Labour and Social Affairs within the project "Arbeitsqualität und wirtschaftlicher Erfolg" ("Quality of work and economic success"). The project and data set are administered at the IAB (Institut für Arbeitsmarktforschung, Institute for Employment Research), and the questionnaires were jointly designed by the Centre for European Economic Research (ZEW, Zentrum für Europäische Wirtschaftsforschung), the Seminar for Personnel Economics and HRM at the University of Cologne and the IAB.[2]

The object of observation in the LPP employer survey is a specific establishment, i.e. a plant or subsidiary of a firm. The establishments for the LPP were drawn from the 2011 wave of the IAB Establishment Panel, an annual representative establishment survey of around 16,000 German establishments that has been conducted since 1993. The IAB Establishment Panel asks employers, among other things, about their workforce characteristics, innovation, investments, sales as well as legal and ownership structure (Fischer et al., 2009). Sampling from those establishments has the advantage that a variety of establishment information is already available (also from past waves of the IAB Establishment Panel), which implies the availability of historical information about the development of the establishments and permits the LPP to focus on specific HR dimensions. 
The LPP sample is restricted to private sector establishments in manufacturing and service sectors with more than 50 employees subject to social security contributions. The sample was stratified according to four employment classes (50-99; 100-249; 250-499; 500 and more employees), five industries (metalworking and electronic industries; further manufacturing industries; retail and transport; services for firms; information and communication services) and four regions of Germany (north; east; south; west).

The establishment survey was carried out by TNS Infratest Sozialforschung, a professional survey institute that also administers the annual IAB Establishment Panel. TNS Infratest Sozialforschung distributed the LPP employer questionnaire after completion of the IAB Establishment Panel questionnaire to the same respondents. This ensures that both data sources are consistent and can be combined. The interviewers addressed CEOs and HR managers in face-to-face interviews between July $30^{\text {th }}$ and October $12^{\text {th }} 2012$. The response rate was 76 per cent of the approached firms. With their participation, the establishments gave their consent to link the LPP survey information to other data sets available through the IAB via a unique, anonymous establishment identifier.

After completion of the field interviews with the employers, employees working in the participating establishments were drawn from the German Social Security Records. Indeed, reports from social security records have a substantial lag of several months. Therefore, a sample of employees who were employed on December $31^{\text {st }} 2011$ in one of the participating firms was drawn.[3] The sample was restricted to participating establishments for which more than 50 employees could be identified that were subject to social security contributions at the end of 2011. Both restrictions reduced our final linked sample to 869 establishments. From those establishments, we drew a gross sample of around 30,000 employees.

The employee survey was carried out by Infas (Institut für angewandte Sozialwissenschaft $\mathrm{GmbH}$ ), a professional survey institute. Infas contacted the employees via telephone at home and carried out 7,508 valid interviews (CATI) between December $3^{\text {rd }} 2012$ and April $3^{\text {rd }} 2013$. The response rate of realized contacts was 34.1 per cent. Finally, 6,051 interviewees gave their permission to link their data to the administrative data and the employer survey of the LPP.

An important additional feature of the LPP is the possibility not only to match the employer and the employee survey but also to link this data to various external sources available through the IAB. For instance, the establishment survey can be linked to the Establishment History Panel (Gruhl et al., 2012).[4] The Establishment History Panel is an administrative record that contains information about workforce characteristics, employment dynamics and the wage structure dating back to the 
establishment's foundation or 1975. Moreover, the employee survey can be linked to the Integrated Employment Biographies (IEB), which contain individual employment spells with information about earnings, employers, job switching, and basic qualifications from the individual's entry into the labour market or 1975 (vom Berge et al., 2013). It is important to stress that the employment information from the IEB is not based on self-reported information by employees but on administrative data reported by the firms to the federal employment office to administer social security contributions. The Establishment History Panel is the aggregation of this IEB information. An important feature of the LPP is that the individual employment biographies are not only available for the 7,508 surveyed employees but also for their non-surveyed co-workers in the establishments covered by the employer survey.

\section{Design of the LPP Surveys}

\section{III.1 Employer Survey}

As the LPP employer survey can be linked to the annual IAB Establishment Panel, the LPP Employer Survey focuses in more detail on HR practices in firms and on additional relevant structural characteristics. Basic information from the regular IAB establishment panel already captures workforce structure and composition (number of employees, share of university graduates, females, part-time employees, quits, new hires, etc.), employee representation (union coverage, works councils, alternative representation forms), ownership structure (foreign ownership, family firm), legal structure (limited company, single-site firms, etc.), establishment-level performance measures (total sales, net profits) and capital intensity of production and service (inputs, investments, standard of technology used etc.).[5] The LPP includes additional structural characteristics such as changes in the ownership structure, organizational structure, and business strategy. Nevertheless, the main focus lies on HRM practices within firms in the four areas "HR planning and recruitment", "HR development", "performance management and remuneration" and "retention, values and corporate culture".

In the area HR planning and recruitment, for instance, firms state information about their use of personnel planning tools and the length and characteristics of the recruitment process. HR development contains survey items about performance appraisals, target agreements between supervisors and employees, as well as feedback mechanisms and provided training. Performance management and remuneration deal with topics such as individual, team and firm-based performance pay and elicits the structure of performance pay. The section on retention, values and 
corporate culture includes items about the use of employee surveys, family-friendly policies, and external certifications and audits.

\section{III.2 Employee Survey}

The employee survey is based on administrative Social Security Records, which already provide a very accurate description of employment spells and salaries, starting with the individual's labour market entry. The LPP employee survey adds a number of socio-demographic questions about marital status, children, occupation, and migration background.

The employee questionnaire further includes detailed survey scales to assess job characteristics, personal characteristics, attitudes and behavioural variables. For most of these questions we implement well-established scales widely used in the literature. In addition, we adopted a number of survey items to measure specific job aspects and employee perceptions about HR instruments.

\section{Definition, Origin and Statistical Properties of the Scales used in the LPP Employee Survey}

This section briefly presents the definitions, origins and statistical properties of the main measures applied in the LPP employee survey. The tables report means, standard deviations, values of internal scale reliability (Cronbach's alpha) and factor loadings. Scales were used that have been established in previous studies. We also compare their internal consistency with that reported in the respective original papers.

It is important to note that the LPP employee survey is a telephone survey with the key intention of giving a broad overview of HR practices and employee perceptions. Due to budget considerations and length requirements, we therefore tried to use short scales that can be administered in a telephone interview.

\section{1 Job Characteristics and Job Perceptions}

The LPP contains a number of items measuring specific aspects of an employee's work contract and job design. In detail, the LPP comprises items eliciting basic job characteristics, aspects of work design, rewards and incentives, and training and development. Beyond these mostly rather objectively measurable characteristics, the LPP employee survey also includes scales measuring more subjective perceptions about job characteristics. 


\section{Basic Job Characteristics}

A first important component of the LPP employee survey is factual information on basic job characteristics, such as the occupational position, whether the employee holds a supervisory position, and in this case on the number of subordinates, the contractual and actual working time, the contractual status (full-time, part-time, fixed-term, or permanent work contract), overtime and overtime compensation, shift work, weekend work, and detailed information on the possibility to work from home.

\section{Work Design}

Work design describes how jobs, tasks and roles are structured, enacted, and modified as well as the impact of these structures, enactments, and modifications on individual, group, and organizational outcomes. (Grant and Parker, 2009). Work design characteristics can be influenced by human resource management practices having an effect on attitudes and behavioural variables (Rhoades and Eisenberger, 2002; Patterson et al., 2005; Humphrey et al., 2007). To describe various workplaces and occupations, Morgeson and Humphrey (2006) developed the Work Design Questionnaire (WDQ), which encompasses 21 items in the four categories task, knowledge, and social characteristics as well as work context.[6] The LPP entails one item each taken from the WDQ scales decision-making autonomy, task variety, initiated interdependence, received interdependence, and physical demands (Table 1). Furthermore, a modified item on work conditions (e.g. noise, temperature) and a measure of time pressure are included.

Table 1: Work design items

\section{Reward and Incentive System}

Compensation and in particular performance-contingent pay is a major driver of employee selection, motivation and performance (Milkovich and Newman, 1996; Lazear, 1999; Prendergast, 1999). The LPP contains a number of variables to describe the salary and reward system. The salary can be measured either with a direct question in the LPP about the net earnings in the last month before the interview, or using the linked administrative social security records, which cover average daily gross earnings of the entire last year and for the entire employment history.[7] The LPP contains further questions regarding performance-related pay. It distinguishes between contractual and noncontractual variable payments (i.e. payments without clear regulations such as spot bonuses) and 
asks about the proportion of performance pay relative to total salary. More detailed information, for instance about the extent to which performance pay is based on individual, team, or company performance, is also elicited in the LPP establishment survey. Furthermore, information on pension benefits is available.

\section{Training and Development}

The LPP contains a number of survey items to elicit whether and to what extent employees have access to personnel and career development practices. Employees are asked about the intensity of formal training (number of days spent in trainings, whether they were released from work during trainings, and how the training cost were split between employer and employee) and about their participation in further training or qualification activities. Additional items focus on details about prescheduled annual appraisal interviews with supervisors (incidence and length of the interview) and whether written target agreements with supervisors are used.

Beyond the more objective items, the survey also includes a number of novel items about employees' subjective perceptions of the way personnel development and promotion decisions are made within their establishment (i.e. whether promotions are based on previous job performance and potential fit for the new position or depend on other factors rather than professional skills and ability, see Table 2). Moreover, one item measures the employees' general perception about the extent to which the employer is investing in his or her human capital. All items are measured on a five-point Likert scale from 1 "strongly disagree" to 5 "strongly agree".

-Table 2: Perceptions about training and development

\section{Supervisory Support}

Perceived supervisory support refers to the degree to which employees perceive that supervisors value their contribution and care about their well-being (Kottke and Sharafinski, 1988; Rhoades and Eisenberger, 2002). Because supervisors are agents of the organization with responsibility for directing and evaluating subordinates' performance, it is commonly argued that employees view their supervisor's favourable or unfavourable orientation towards them as indicative of organizational support (Eisenberger et al., 1986; Rhoades and Eisenberger, 2002).

Patterson et al. (2005) derived a comprehensive organizational climate questionnaire describing various climate dimensions. We use three out of the five-items from their perceived supervisory 
support scale measured on a five-point Likert scale (Table 3). The chosen three items have an internal consistency of alpha=.84, which is very close to the value of .88 of the original five-item scale.

\section{Clarity of Organizational Goals}

Clarity of Organizational goals is concerned with measuring the employees' awareness about clearly defined goals of an organization (Patterson et al., 2005). The specificity of organizational goals could affect work motivation through its influence on job-level goal specificity. In particular, if the goals of an organization are ambiguous, then the goals held at the job level are also likely to be more ambiguous. It has been argued that the clarity of organizational goals may allow supervisors and peers to be more able to provide summative or formative evaluations of an employee's performance that can help to clarify job and performance expectations (Wright, 2004).

Moreover, the clarity of organizational goals can facilitate the coordination of behaviour of employees in different organizational units and lead to more consistent actions, which, in turn, may raise organizational performance (see for instance Kreps, 1990 or Hermalin, 2012 for a discussion on the economic benefits of coordination and corporate culture).

Table 3: Supervisory support and clarity of organisational goals

We use two of the five-item clarity of organizational goals scale borrowing from the organizational climate questionnaire by Patterson et al. (2005). The two items have an internal consistency of alpha=.69, which is below the value of .87 of the original five-item scale. Statistical properties of the supervisory support and clarity of organizational goals scale are shown in Table 3.

\section{Perceived Fairness/Justice}

Employees' fairness perceptions are often divided into three subdimensions: distributive, procedural, and interactional justice. Distributive justice refers to fairness of outcomes, procedural justice to fairness about the processes by which outcomes are allocated (decision-making) and interactional justice to fairness about interpersonal treatment, or the degree to which employees are treated with dignity, politeness, and respect (Cropanzano and Greenberg, 1997; Lind, 2001). Psychologists and management researchers have stressed the role of fairness concerns for organizational outcomes for decades. More recently, economists have incorporated fairness concerns in models of incentive contracting and have extensively studied the performance effects of fairness concerns in 
experimental studies (see, for instance, Gächter and Fehr, 2002 or Camerer and Malmendier, 2012 for overviews).

Holtz and Harold (2009) show that overall justice perceptions are not stable over time, with roughly a quarter of the total variance in overall justice perceptions varying within persons. We take one item each from the distributive, procedural, and interactional justice scales developed by Kim and Leung (2007), as shown in table 4.

Table 4: Perceived fairness/justice measures

\section{Work-Family and Family-Work Conflict}

Work-family and family-work conflicts refer to inter-role conflicts that occur if a person's membership in one group generates pressure on the role responsibilities of another group's membership (Kahn et al., 1964). Such role conflicts occur if either the family domain is constrained by the work role (work-family conflict) or the work domain is negatively affected by family responsibilities (family-work conflict) (Greenhaus and Beutell, 1985).

Work-family and family-work conflict measures are taken from Netemeyer et al. (1996). We integrate three out of five items of each scale in the LPP employee survey (Table 5). The internal consistency of the work-family conflict scale in the LPP $(0.86)$ is very similar to the original values of $0.88-0.89$ reported by Netemeyer et al. (1996), whereas the value for the family-work conflict scale in the LPP $(0.70)$ is lower than the ones reported in the original paper (0.82-0.90).

Table 5: Work-family and family-work conflict

\section{IV.2 Personal Characteristics}

Big Five Personality Traits

The Big Five personality traits are a well-established taxonomy to measure an individual's personality that has been validated in a series of psychological studies (see, for instance, Barrick and Mount, 1991; Costa and McCrae, 1995; Judge and Illies, 2002) and is now widely adopted in psychological 
research. The five broad, non-overlapping dimensions that describe an individual's personality are extraversion, conscientiousness, agreeableness, neuroticism, and openness to experience. Personality traits have been found to be rather stable over time (Lucas and Donnellan, 2011; Hahn et al., 2012).

The LPP measures the Big Five personality traits by applying a 16-item version of the Big Five Inventory short scale (BFI-S) developed for the SOEP (Gerlitz and Schupp, 2005, Lang et al., 2011). Four of the five personality dimensions are measured by three items, whereas the openness to experience dimension includes four items. All statements begin with "I see myself as someone who". Moreover, we apply a five-point Likert scale ranging from 1 (does not apply to me at all) to 5 (applies to me perfectly) instead of the SOEP 7-point Likert scale.

Table 6: Big Five Inventory short scale

Table 6 shows the items and factor loadings and compares the internal consistency for each of the Big Five dimensions of the LPP with those of the wave 2009 of the SOEP (SOEP, v28).[8] Values of Cronbach's alpha are somewhat lower for all dimensions of the Big Five in the LPP compared to the wave 2009 of the SOEP (Richter et al., 2013). One possible reason for this is the survey method. The LPP employee survey asks participants via telephone (CATI), whereas the SOEP survey uses different survey methods such as CAPI, PAPI, and self-administered completion of questionnaires with or without an interviewer present. Depending on the interview method applied, values of internal consistency differ also in the SOEP (Lang et al., 2011). Notably, the reliability measures of the personality items are somewhat lower than the usually acceptable range. However, this is in line with previous research showing that shorter personality scales usually have a lower Cronbach's alpha, but nevertheless show the expected correlations to individual attributes and behavioural variables (Gosling et al, 2003).

\section{Risk Attitudes and Trust}

Although most decisions in life have to be made in situations of uncertainty, people differ in the extent to which they are willing to take risks (risk aversion is experimentally elicited, for instance, in Holt and Laury, 2002). In their seminal paper, Kahneman and Tversky (1979) state that people evaluate the consequences of their decisions relative to a reference point as either gains or losses, where the negative consequence of a loss in individual utility is weighted higher relative to the 
positive impact of a gain in utility. Loss aversion typically leads to risk averse behavior. We integrate the single item eliciting risk attitudes adapted from the individual questionnaire of the SOEP. Risk attitude is measured by the item "Are you generally a person who is fully prepared to take risks or do you try to avoid taking risks?" on a 11-point Likert scale ranging from 0 (risk averse) to 10 (fully prepared to take risks) with an average value of 5.7 ( $\mathrm{sd}=1.84)$, which is quite comparable to the average value of 5.1 ( $s d=2.13$ ) of the 2012 SOEP wave. Dohmen et al. (2012) have experimentally validated this survey question and shown that it predicts actual risk-taking behaviour in experimental lottery choices.

Trust describes the relationship between a trustor and a trustee. A trust relationship exists without a contract signed solely based on a belief in the honesty and promise of another person. Coleman and Coleman (1994) describe it as "the action of placing trust involves the trustor's voluntarily placing resources at the disposal of another party (the trustee), without any real commitment from that other party." Trust and trustworthiness have been extensively studied in experimental economics, and experimentally validated questions on trust and trustworthiness have been implemented in representative surveys such as the SOEP (Fehr et al. 2003).

The LPP measures trust with two of three trust items included in the German Socio Economic Panel Study, which are taken in waves 2003 and 2008 of the survey (Naef and Schupp, 2009). Both items are measured on a five-point Likert scale from "totally agree" to "totally disagree" and show an internal consistency of alpha $=0.50$, which is somewhat lower than the value of 0.63 of the original three-item scale in the wave 2008 of the SOEP. Descriptive statistics of the risk attitude and trust scales are depicted in Table 7.

Table 7: Risk attitudes and trust

\section{Justice Sensitivity}

People systematically differ with respect to how they perceive injustice or potentially unfair treatment and how they react to this phenomenon (Schmitt et al., 2010). Psychologists typically differentiate between four perspectives of injustice: victim sensitivity, observer sensitivity, beneficiary sensitivity, and perpetrator sensitivity. In an influential paper in economics, Fehr and Schmidt (1999) argue that fairness concerns can be captured by measuring the extent to which 
people dislike disadvantageous inequity (i.e., being worse off than others) and advantageous inequity (i.e., being better off than others).

The LPP includes two justice sensitivity items taken from the eight items justice sensitivity inventory short scale survey USS-8 (Schmitt et al., 2010; Beierlein et al., 2012). The USS-8 includes two items for each of the four scales victim, observer, beneficiary, and perpetrator sensitivity. We take one item from the victim and one item from the beneficiary scale (see Table 8) that reflect disadvantageous and advantageous inequity.

Table 8: Justice sensitivity

\section{3 Attitudes towards the Organisation}

While personnel and organizational economists have mainly focussed on behavioural outcomes and organizational performance when studying the impact of HR practices, psychologists and management researchers have put a strong emphasis on employees' attitudes towards the organization. It has been shown that employee attitudes are strong predictors for behavioural variables such as absenteeism, performance, and turnover (Meyer et al., 2002; Schaufeli and Bakker, 2004; Llorens et al., 2006; Mauno et al. 2007; Rich et al., 2010). The LPP comprises attitudes that likely predict individual performance (work engagement) and those that more likely predict turnover (affective commitment and job satisfaction).

\section{Work Engagement}

Work engagement is defined as a positive, affective-motivational state of fulfilment that is characterized by vigour, dedication, and absorption in the job (Schaufeli et al., 2006). It represents the active allocation of personal resources towards the tasks associated with the work role (Rich et al., 2010). Work engagement comprises the three sub-scales: vigour, dedication and absorption. Vigour refers to high levels of energy and resilience, the willingness to invest effort in one's job, not being easily fatigued, and persistence in the face of difficulties. Dedication refers to a strong involvement in one's work, accompanied by feelings of enthusiasm and significance, and by a sense of pride and inspiration. Absorption refers to a pleasant state of immersion in one's work that is characterized by time passing quickly and being unable to detach oneself from the job (Schaufeli et al., 2002; Schaufeli and Bakker, 2004).[9] We note that this scale could also be useful for research in 
personnel economics. While personnel economists in the past had mostly focussed on extrinsic motivation of employees, more recently a literature has emerged in economics studying the role of intrinsic motivation and its interplay with extrinsic incentives when determining employee efforts (see e.g. Frey and Oberholzer-Gee, 1997; Bénabou and Tirole, 2003; Sliwka, 2007; Ellingsen and Johanneson, 2008). As employee efforts are typically hard to measure objectively with a unified measure that is comparable across industries and jobs, a subjective scale measuring the extent to which employees are engaged in their jobs seems to be an important complement when studying the association between the use of HR instruments and firm performance.

In the LPP employee survey, work engagement is operationalized with the nine-item short scale of the Utrecht Work Engagement Scale (UWES-9) (Schaufeli et al., 2002; Schaufeli and Bakker, 2004). Table 9 shows the nine scale items and factor loadings. The LPP overall work engagement shows an internal consistency of alpha $=0.91$ (Table 9), which is very close to the alpha of 0.90 of the total database reported by Schaufeli and Bakker (2004). Similarly, the sub-scales have a high internal consistency of 0.71 (vigour), 0.82 (dedication) and 0.84 (absorption) all of which are comparable to the original alpha measures of 0.72 (vigour), 0.84 (dedication), and 0.77 (absorption).

Table 9: Work engagement short scale

\section{Affective Commitment}

Commitment describes the relative strength of an individual's identification with and involvement in a particular organization. The most influential concept of commitment is the three-component model (Allen and Meyer, 1990; Meyer and Allen, 1991; Meyer et al., 1993). The model distinguishes affective, continuance, and normative commitment. Even if all three dimensions describe employees' attachment to the firm, affective commitment is generally considered to be the most important dimension to predict individual turnover intention, job performance, citizenship behaviour or absenteeism (Meyer et al., 2002). Affective commitment describes employees' emotional attachment and that he or she enjoys membership in the organization.[10]

We apply the six-item short form to measure affective commitment to the organization introduced by Meyer et al. (1993). This construct is a reduced but embedded scale of the original version introduced by Allen and Meyer (1990). Responses were made on a five-point Likert scale (in the original study a 7-point Likert scale was used). Table 10 reports the scale items, factor loadings, and 
Cronbach's alpha of the construct. The internal consistency of the affective organizational commitment scale in the LPP is alpha $=0.83$, which is similar to the value reported in the sample used by Meyer et al. (1993) of alpha $=0.82$ and the alpha $=0.82$ based on 144 studies reported in the meta study by Meyer et al. (2002).

Table 10: Items and factor loadings of affective commitment

\section{Employee Well-being}

Employee or psychological well-being is often referred to as a sub dimension of overall happiness that predict job performance (Wright and Cropanzano, 2000). Wright (2005) even claims that wellbeing is a better predictor of job performance than job satisfaction, but evidence of this relationship is missing from meta-studies.

In the LPP, we apply the WHO-5-Well-Being Questionnaire (version 1998), a frequently used selfrated 5-item questionnaire of emotional wellbeing (Bech et al., 2003). Survey respondents rate five statements about how they have felt over the last two weeks, measured on a six-point scale from 0 "at no time" to 5 "all of the time" (Table 11). The LPP scale shows an internal reliability of 0.84.

Table 11: Items and factor loadings of WHO-5

\section{Job and Income Satisfaction}

Job Satisfaction, a domain-specific element of life satisfaction, is the subjective evaluation of an employee's well-being with respect to her current work or with aspects of her work. Economists often interpret job satisfaction as the utility of an employee's present job determined by monetary and non-monetary aspects (Hamermesh, 1977; Freeman, 1978). Correspondingly, income satisfaction refers to the evaluation of an employee's well-being with her income.

The LPP measures job and income satisfaction with one item for each taken from the German SocioEconomic Panel Study (SOEP). Employees assess their level of job and income satisfaction on an 11point Likert scale ranging from 0 (completely dissatisfied) to 10 (completely satisfied, compare Table 12). Mean job satisfaction reported in the LPP is 7.56 ( $s d=1.75)$, which is somewhat larger than the 
respective average in the SOEP wave 2012, with an average satisfaction of 7.0 (sd $=1.97)$. Mean income satisfaction is 6.67 (sd = 2.17), which is similar to the SOEP 2012 wave with mean 6.62 (sd = 2.13).

Table 12: Mean and standard deviation of the satisfaction measures

\section{4 Behavioural Variables}

Finally, the LPP gives access to variables that match actual employee behaviour to a stronger extent.

\section{Turnover Intention}

Turnover intention is defined as a conscious and deliberate willingness to leave the organization, often combined with the intent to search for alternative employment (Tett and Meyer, 1993). It has been shown that turnover intention is a strong predictor for actual turnover (Tett and Meyer, 1993; Griffeth et al., 2000).

The LPP measures the probability that an employee stays with the current employer with the single item "How many times in the past 12 months have you thought about changing your job?" (Table 13). The answer categories on a five-point Likert scale ranged from 1 (never) to 5 (every day), with a mean value of $1.61(s d=0.93)$. Such a single-item measure of turnover intention is usually correlated to a weaker extent to job satisfaction and commitment as compared to a longer scale but is still significantly correlated to employee attitudes (Tett and Meyer, 1993).

\section{Real turnover}

Real turnover can be measured in two ways in the LPP. First, starting with the second wave of the employee survey, the surveyed employees are asked whether they still work in the same firm. If this is not the case, they respond to a specific "job mover" questionnaire collecting detailed information on their job changes. Moreover, turnover can be very accurately measured using the linked Integrated Employment Biographies (IEB) from the administrative data. The IEB are usually available with a time lag of two years and updated annually. The IEB includes the exact time spell of all employment spells at the current and each prospective employer. Since the social security records are the source for pension or unemployment claims, this administrative source is very accurate. Moreover, actual turnover can be tracked even in the years after the LPP survey has been conducted. 


\section{Sickness absence}

Sickness absence refers to any unscheduled absence from the workplace due to illness, i.e. scheduled absence such as holidays are not considered. In the LPP, we integrate one single item on sickness absence taken from the German Socio-economic panel study (SOEP) which captures sickness absence as the days an employee had been unable to work during the previous 12 months. The mean value is $11.65(s d=24.32)$ and the median value is 4 days. The variable ranges from 0 to a maximum of 230 .

Table 13: Behavioural variables

\section{$v$ Correlation between the Scales}

Table A1 in the appendix displays the means, standard deviations, and pairwise correlations of all factors introduced in section IV. The correlations show the expected signs. The strongest correlations are between income satisfaction and fairness (0.62) and supervisory support and fairness (0.57). Hence, all variables describe reasonable distinct concepts.

\section{Further Development and Data Access}

This paper introduced the LPP data and describes the first wave of the employer and employee survey, both collected in 2012/ 2013. But the LPP is designed as a longitudinal linked employeremployee data set. The second wave of the employer and employee survey was collected in 2014/ 2015. The project stakeholders agreed to support and fund a third wave that will be collected in 2016 and discuss continuing the data collection in the future. The majority of the survey questions both in the employer and employee data set are scheduled to be asked in an identical way in each wave in order to establish the possibility for long-term comparisons and panel analyses. A small fraction of items will be modified in each wave in order to focus on relevant topics that are present at the time of each data collection. Hence, the LPP will constitute a detailed and longitudinal data source for HR researchers and personnel economists now and in the future.

The first wave of the LPP has been available for researchers since spring 2015. The second wave will presumably be available in spring 2017. Researchers can apply to use the data at the Research Data Centre of the Institute for Employment Research in Nuremberg.[11] There are two ways to access the data: via on-site use at one of the Research Data Centres in Germany or around the world or via remote data access. On-site use requires that the researcher travels to a Research Data Centre but it allows him or her to directly assess the data. Remote data access is possible after an initial on-site 
access to get acquainted with the data. It requires sending program codes to the Research Data Centre, which then returns the corresponding result files. In both cases, the Research Data Centre is required to double check the data protection regulations before releasing the final files to the researchers.

\section{Conclusion}

The main advantage of the LPP lies in the integration of standard measures of job characteristics and job perceptions, personal characteristics, attitudes towards the organisation and behavioural variables in a longitudinal, representative linked employer-employee data set. This integration allows researchers to tackle a number of research questions, first, to analyse associations between a broad set of specific HR instruments used on the firm level and employee attitudes and behaviour. Second, it allows to study the role of context for well-established relationships between HR instruments and employee attitudes. Third, the integration enables to illustrate the time variability of HR management practices, and fourth, to go beyond mere cross-sectional correlations and thus come closer to the ideal of establishing causal effects of HR practices. The last two points are more likely to be addressed when the longitudinal dimension of the data set becomes available in the near future. Research focussing on a potential context dependency of well-known relationships is already feasible.

Empirical researchers in the field of organisational behaviour or personnel economics often have to rely either on rather broad individual surveys like the SOEP, PSID or the NLSY that cannot be matched to firm-level information or on small data sets limited to specific firms or occupations.[12] This usually raises the question whether the results can be generalized to other environments and to what extent the specific context matters. The LPP should be well suited to investigate such questions. First, the LPP is representative for private sector firms in Germany, which allows, for instance, a comparison between industries and according to firm size. Second, the LPP links the employer and employee dimension and allows for investigating differences between several HR and business practices and employees' perceptions about these practices. Third, the LPP can be linked to administrative information about actual salaries and employment histories. Fourth, the LPP uses several survey scales that are well established in the literature.

The LPP of course also has some limitations. The employee questionnaire contains a number of variables that include only a subset of standard scales such as the work design variables, clarity of organisational goals or supervisory support. The reason for shortening well-established scales or choosing specific items is found in the specific construction of the employee survey. The employee 
survey was collected by a professional survey institute. This has the advantage of a high data quality and response rate but also entails high costs per interview. Hence, the project budget restricts the number of items and the items were chosen in a way that they are likely to cover all relevant areas of the respective concepts. Moreover, the telephone survey took about 30 minutes on average further lengthening the survey probably would have reduced the response rate.

Moreover, of course employee level information is mostly based on subjective perceptions and the data set cannot directly provide objective measures of employee performance. However, we note that it is a future aim at the IAB which administers the survey to link the data set also to financial databases allowing to use balance sheet data to measure firm success.

\section{References}

Allen, N.J. and Meyer, J.P. (1990), "The measurement and antecedents of affective, continuance and normative commitment to the organization", Journal of Occupational Psychology, Vol. 63 No. 1, pp. 1-18.

Barrick, M.R. and Mount, M.K. (1991), "The big five personality dimensions and job performance: A meta-analysis", Personnel Psychology, Vol. 44 No. 1, pp. 1-26.

Bech, P., Olsen, L.R., Kjoller, M. and Rasmussen, N.K. (2003), "Measuring well-being rather than the absence of distress symptoms: a comparison of the SF-36 Mental Health subscale and the WHOFive well-being scale", International Journal of Methods in Psychiatric Research, Vol. 12 No. 2, pp. 85-91.

Beierlein, C., Baumert, A., Schmitt, M., Kemper, C. J., Kovaleva, A. and Rammstedt, B. (2012), “Kurzskalen zur Messung der Ungerechtigkeitssensibilität: Die Ungerechtigkeitssensibiliät-Skalen8 (USS-8)“, GESIS-Working Papers 2012|21, GESIS, Mannheim.

Bellmann, L., Bender, S., Bossler, M., Broszeit, S., Dickmann, C., Gensicke, M., Gilberg, R., Grunau, P., Kampkötter, P., Laske, K., Mohrenweiser, J., Schröder, H., Schütz, H., Sliwka, D., Steffes, S., Stephani, J., Tschersich, N., and Wolter S. (2015), „LPP - Linked Personnel Panel. Quality of work 
and economic success: longitudinal study in German establishments (data collection on the first wave)", FDZ-Methodenreport, 05/2015, IAB, Nuremberg.

Benabou, R. and Tirole, J. (2003), "Intrinsic and extrinsic motivation", The Review of Economic Studies, Vol. 70 No. 3, pp. 489-520.

Bloom, N. and Van Reenen, J. (2007), "Measuring and Explaining Management Practices Across Firms and Countries", The Quarterly Journal of Economics, Vol. 122 No. 4, pp. 1351-1408.

Bloom, N. and Van Reenen, J. (2010), "Why Do Management Practices Differ across Firms and Countries?", Journal of Economic Perspectives, Vol. 24 No. 1, pp. 203-224.

Bluedorn, A.C. (1982), "A unified model of turnover from organizations", Human relations, Vol. 35 No. 2, pp. 135-153.

Broszeit, S. and Wolter, S. (2015), “LPP - Linked Personnel Panel. Quality of work and economic success: longitudinal study in German establishments (data documentation on the first wave)", FDZ-Datenreport, 01/2015, IAB, Nuremberg.

Camerer, C. and Malmendier, U. (2007), "Behavioral Economics of Organizations", in Diamond, P. and Vartiainen H. (Eds.): Behavioral Economics and Its Applications. Princeton University Press, Princeton, pp. 235-275.

Coleman, J.S. and Coleman, J.S. (1994), "Foundations of social theory", Harvard University Press, Cambridge, Massachusetts.

Costa Jr., P.T. and McCrae, R.R. (1995), "Domains and facets: Hierarchical personality assessment using the revised neo personality inventory", Journal of Personality Assessment, Vol. 64 No. 1, pp. 21-50.

Cropanzano, R. and Greenberg, J. (1997), "Progress in organizational justice: Tunneling through the maze", International Review of Industrial and Organizational Psychology, Vol. 12, pp. 317-372.

Dohmen, T., Falk, A., Huffman, D., Sunde, U., Schupp, J. and Wagner, G.G. (2011), “Individual risk attitudes: Measurement, determinants, and behavioral consequences", Journal of the European Economic Association, Vol. 9 No. 3, pp. 522-550.

Eisenberger, R., Huntington, R., Hutchison, S. and Sowa, D. (1986), "Perceived organizational support", Journal of Applied Psychology, Vol. 71 No. 31, pp. 500-507.

Ellingsen, T. and Johannesson, M. (2008), "Pride and Prejudice: The Human Side of Incentive Theory", The American Economic Review. Vol. 98 No. 3, pp. 990-1008. 
Fehr, E., Fischbacher, U., Rosenbladt, B. v., Schupp, J. and Wagner, G.G. (2003), "A Nation-Wide Laboratory: Examining Trust and Trustworthiness by Integrating Behavioral Experiments into Representative Surveys", IZA Discussion Paper No. 715, IZA, Bonn.

Fehr, E. and Schmidt, K.M. (1999), "A theory of fairness, competition, and cooperation", Quarterly Journal of Economics, Vol. 114 No. 3, pp. 817-868.

Fischer, G., Janik, F., Müller, D. and Schmucker, A. (2009), "The IAB Establishment Panel, things users should know", Schmollers Jahrbuch. Zeitschrift für Wirtschafts- und Sozialwissenschaften, Vol. 129 No. 1, pp. 133-148.

Freeman, R. (1978), "Job Satisfaction as an Economic Variable", American Economic Review, Vol. 68 No. 2, pp. 135-141.

Frey, B. S. and Oberholzer-Gee, F. (1997), "The cost of price incentives: An empirical analysis of motivation crowding-out", The American Economic Review, Vol. 87 No. 4, pp. 746-755.

Gächter, S. and Fehr, E. (2002), „Fairness in the Labour Market - A Survey of Experimental Result”, in Bolle, F. and Lehmann-Waffenschmidt, S. (Eds.), Surveys in Experimental Economics. Bargaining, Cooperation and Election Stock Markets. Physica Verlag, Heidelberg, pp. 95-132.

Gerlitz, J.-Y. and Schupp, J. (2005), "Zur Erhebung der Big-Five-basierten Persönlichkeitsmerkmale im SOEP (The measurement of the Big Five personality traits in the SOEP)", working paper, DIW Berlin.

Gosling, S.D., Rentfrow, P.J. and Swann, W.B. (2003), "A very brief measure of the Big-Five personality domains", Journal of Research in Personality, Vol. 37 No. 6, pp. 504-528.

Grant, A.M. and Parker, S.K. (2009), "7 redesigning work design theories: the rise of relational and proactive perspectives", The Academy of Management Annals, Vol. 3 No. 1, pp. 317-375.

Greenhaus, J.H. and Beutell, N.J. (1985), "Sources of conflict between work and family roles", Academy of Management Review, Vol. 10 No. 1, pp. 76-88.

Griffeth, R.W., Hom, P.W. and Gaertner, S. (2000), “A Meta-analysis of Antecedents and Correlates of Employee Turnover, Update, Moderator Tests, and Research Implications for the Next Millennium", Journal of Management, Vol. 26 No. 3, pp. 463.488.

Gruhl, A., Schmucker, A. and Seth, S. (2012), "The Establishment History Panel 1975-2010: Handbook version 2.2.1", FDZ-Datenreport, 04/2012, IAB Nuremberg. 
Hahn, E., Gottschling, J. and Spinath, F.M. (2012), "Short measurements of personality? Validity and reliability of the GSOEP big five inventory (BFI-S)", Journal of Research in Personality, Vol. 46 No. 3, pp. 355-359.

Hamermesh, D. (1977), "Economic Aspects of Job Satisfaction", in Ashenfelter, O. and Oates, W. (Eds), Essays in Labor Marker Analysis, John Wiley, New York, pp. 53-72.

Hermalin, B. (2012), "Leadership and corporate culture", in Gibbons, R. and Roberts, J. (Eds.), Handbook of Organizational Economics, Princeton University Press, Princeton, pp. 432-478.

Holt, C.A. and Laury, S.K. (2002), "Risk aversion and incentive effects", American Economic Review, Vol. 92 No. 5, pp. 1644-1655.

Holtz, B.C. and Harold, C.M. (2009), "Fair today, fair tomorrow? A longitudinal investigation of overall justice perceptions", Journal of Applied Psychology, Vol. 94 No. 5, pp. 1185-1199.

Humphrey, S.E., Nahrgang, J.D. and Morgeson, F.P. (2007), "Integrating motivational, social, and contextual work design features: a meta-analytic summary and theoretical extension of the work design literature", Journal of Applied Psychology, Vol. 92 No. 5, pp. 1332-1356.

Judge, T.A. and Ilies, R. (2002), "Relationship of personality to performance motivation: A metaanalytic review", Journal of Applied Psychology, Vol. 87 No. 4, pp. 797-807.

Kahn, R.L., Wolfe, D.M., Quinn, R., Snoek, J.D. and Rosenthal, R.A. (1964), "Organizational stress", John Wiles, New York, NY.

Kahneman, D. and Tversky, A. (1979), "Prospect theory: An analysis of decision under risk", Econometrica, Vol. 47 No. 2, pp. 263-291.

Kim, T.Y. and Leung, K. (2007), "Forming and reacting to overall fairness: A cross-cultural comparison", Organizational Behavior and Human Decision Processes, Vol. 104 No. 1, pp. 83-95.

Kottke, J. and Sharafinski, C. (1988), "Measuring perceived supervisory and organizational support", Educational and Psychological Measurement, Vol. 48 No. 4, pp. 1075-1079.

Kreps, D.M. (1990), "Corporate Culture and Economic Theory", in Alt, J. and Shepsle, K. (Eds.), Perspectives on Positive Political Economy, Cambridge University Press, Cambridge, UK, pp. 90143.

Lang, F.R., John, D., Lüdtke, O., Schupp, J. and Wagner, G.G. (2011), "Short assessment of the Big Five: Robust across survey methods except telephone interviewing", Behavior Research Methods, Vol. 4 No. 2, pp. 548-567. 
Lazear, E.P. (2000), "Performance Pay and Productivity", American Economic Review, Vol. 90 No. 5, pp. 1346-1361.

Lind, E.A. (2001), "Fairness heuristic theory: Justice judgements as pivotal cognitions in organizational relations", in Greenberg, J. and Cropanzano, R. (Eds.), Advances in Organization Justice, Stanford University Press, Stanford, CA, pp. 56-88.

Llorens, S., Bakker, A.B., Schaufeli, W. and Salanova, M. (2006), "Testing the robustness of the job demands-resources model", International Journal of Stress Management, Vol. 13 No. 3, pp. 378391.

Lucas, R.E. and Donnellan, M.B. (2011), "Personality development across the life span: Longitudinal analyses with a national sample from Germany", Journal of Personality and Social Psychology, Vol. 101 No. 4, pp. 847-861.

Mauno, S., Kinnumen, U. and Ruokolainen, M. (2007), "Job Demands and resources as antecedents of work engagement: a longitudinal study", Journal of Vocational Behavior, Vol. 70 No. 1, pp. 149-171.

Meyer, J.P. and Allen, N.J. (1991), "A three-component conceptualization of organizational commitment", Human Resource Management Review, Vol. 1 No. 1, pp. 61-89.

Meyer, J.P., Allen, N.J. and Smith, C.A. (1993), "Commitment to organizations and occupations: Extension and test of a three-component conceptualization", Journal of Applied Psychology, Vol. 78 No. 4 , pp. 538-551.

Meyer, J.P., Stanley, D.J., Herscovitch, L. and Topolnytsky, L. (2002), “Affective, continuance, and normative commitment to the organization: A meta-analysis of antecedents, correlates, and consequences", Journal of Vocational Behavior, Vol. 61 No. 1, pp. 20-52.

Milkovich, G.T. and Newman J.M. (1996), “Compensation”, Irwin, Chicago., IL.

Morgeson, F.P. and Humphrey, S.E. (2006), "The Work Design Questionnaire (WDQ): Developing and validating a comprehensive measure for assessing job design and the nature of work", Journal of Applied Psychology, Vol. 91 No. 6, pp. 1321-1339.

Naef, M. and Schupp, J. (2009), "Measuring Trust: Experiments and Surveys in Contrast and Combination", SOEPpapers on Multidisciplinary Panel Data Research 167, DIW, Berlin.

Netemeyer, R.G., Boles, J.S. and McMurrian, R. (1996), "Development and validation of work-family conflict and family-work conflict scales", Journal of Applied Psychology, Vol. 81 No. 4, pp. $400-$ 410. 
Patterson, M.G., West, M.A., Shackleton, V.J., Dawson, J.F., Lawthom, R., Maitlis, S. and Wallace, A.M. (2005), "Validating the organizational climate measure: links to managerial practices, productivity and innovation", Journal of Organizational Behavior, Vol. 26 No. 4, pp. 379-408.

Prendergast, C. (1999), "The provision of incentives in firms", Journal of Economic Literature, Vol. 37 No. 1, pp. 7-63.

Rhoades, L. and Eisenberger, R. (2002), "Perceived organizational support: a review of the literature", Journal of Applied Psychology, Vol. 87 No. 4, pp. 698-714.

Rich, B.L., Lepine, J.A. and Crawford, E.R. (2010), “Job engagement: Antecedents and effects on job performance", Academy of Management Journal, Vol. 53 No. 3, pp. 617-635.

Richter, D., Metzing, M., Weinhardt, M. and Schupp, J. (2013), "SOEP scales manual", SOEP Survey Papers, No. 138, DIW, Berlin.

Schaufeli, W.B., Salanova, M., Gonzalez-Roma, V. and Bakker, A.B. (2002), "The measurement of engagement and burnout: A two sample confirmatory factor analytic approach", Journal of Happiness Studies, Vol. 3 No. 1, pp. 71-92.

Schaufeli, W.B. and Bakker, A.B. (2004), "Utrecht Work Engagement Scale Preliminary Manual, Version 1.1", Utrecht, Netherlands.

Schaufeli, W.B., Salanova, M. and Bakker, A.B. (2006), "The measurement of Work Engagement with a Short Questionnaire: a Cross-National Study", Education and Psychological Measurement Vol. 66 No. 4, pp. 701-716.

Schmitt, M., Baumert, A., Gollwitzer, M. and Maes, J. (2010), "The Justice Sensitivity Inventory: Factorial validity, location in the personality facet space, demographic pattern, and normative data", Social Justice Research, Vol. 23 No. 2-3, pp. 211-238.

Sliwka, D. (2007), "Trust as a Signal of a Social Norm and the Hidden Costs of Incentive Schemes", American Economic Review, Vol. 97 No. 3, pp. 999-1012.

Tett, R.P. and Meyer, J.P. (1993), "Job satisfaction, organizational commitment, turnover intention, and turnover: path analyses based on meta-analytic findings", Personnel Psychology, Vol. 46 No. 2, pp. 259-293.

vom Berge, P., König, M. and Seth, S. (2013), "Sample of Integrated Labour Market Biographies (SIAB) 1975-2010", FDZ-Datenreport, 01/2013, IAB, Nuremberg. 
Wright, B.E. (2004), "The role of work context in work motivation: A public sector application of goal and social cognitive theories", Journal of Public Administration Research and Theory, Vol. 14 No. 1, pp. 59-78.

Wright, T.A. (2005), "The role of 'happiness'in organizational research: Past, present and future directions", in Perrewe, P.L. and Ganster, D.C. (Eds.), Research in occupational stress and wellbeing, Vol. 4, JAl, Amsterdam, pp. 225-268.

Wright, T.A. and Cropanzano, R. (2000), "Psychological well-being and job satisfaction as predictors of job performance", Journal of Occupational Health Psychology, Vol. 5 No. 1, pp. 84-94. 
Table 1: Work design items

\begin{tabular}{|c|c|c|}
\hline Construct & Item & Mean (std. dev.) \\
\hline $\begin{array}{l}\text { Decision-making } \\
\text { autonomy }\end{array}$ & $\begin{array}{l}\text { The job allows me to make a lot of decisions on my } \\
\text { own. }\end{array}$ & $1.98(1.0)$ \\
\hline Task variety & The job involves a great deal of task variety. & $1.75(0.95)$ \\
\hline $\begin{array}{l}\text { Initiated } \\
\text { interdependence }\end{array}$ & Other jobs depend directly on my job. & $2.06(1.18)$ \\
\hline $\begin{array}{l}\text { Received } \\
\text { interdependence }\end{array}$ & $\begin{array}{l}\text { The job depends on the work of many different } \\
\text { people for its completion. }\end{array}$ & $2.64(1.33)$ \\
\hline Physical demands & The job requires a lot of physical effort. & $3.65(1.47)$ \\
\hline $\begin{array}{l}\text { Work conditions } \\
\text { (modified) }\end{array}$ & $\begin{array}{l}\text { At work I am exposed to unpleasant ambient } \\
\text { conditions such as noise, extreme temperature, } \\
\text { unpleasant lightning or odours. }\end{array}$ & $3.26(1.55)$ \\
\hline Time pressure & $\begin{array}{l}\text { I often have time pressure over a long period or I have } \\
\text { to deal with several important tasks at the same time. }\end{array}$ & $2.45(1.24)$ \\
\hline
\end{tabular}

The items are taken/adapted from the Work Design Questionnaire by Morgeson and Humphrey (2006) and are measured on a five-point Likert Scale. 
Table 2: Perceptions about training and development

\begin{tabular}{|l|c|}
\hline \multicolumn{1}{|c|}{ Item } & Mean (std. dev.) \\
\hline $\begin{array}{l}\text { Our establishment is substantially interested in further development of my } \\
\text { professional knowledge and competences. }\end{array}$ & 3.59 (1.22) \\
\hline $\begin{array}{l}\text { In our establishment, employees expected to fit the new position best are } \\
\text { predominantly promoted. }\end{array}$ & 3.49 (1.23) \\
\hline $\begin{array}{l}\text { In our establishment, employees characterized by outstanding previous job } \\
\text { performance are predominantly promoted. }\end{array}$ & 3.37 (1.24) \\
\hline $\begin{array}{l}\text { In our establishment, promotions are mostly not based on professional } \\
\text { criteria or job performance. }\end{array}$ & 2.46 (1.27) \\
\hline $\begin{array}{l}\text { In the past two years within this establishment, I have been disadvantaged } \\
\text { in personnel decisions, such as promotion, salary raise, performance } \\
\text { appraisal or further training. }\end{array}$ & 1.78 (1.28) \\
\hline
\end{tabular}

All items are measured on a five-point Likert scale. 
Table 3: Supervisory support and clarity of organisational goals

\begin{tabular}{|l|c|c|}
\hline \multicolumn{1}{|c|}{ Items (mean; std. dev.) } & \multicolumn{2}{c|}{$\begin{array}{c}\text { Cronbach's alpha/ } \\
\text { Factor loadings }\end{array}$} \\
\hline & LPP & $\begin{array}{c}\text { Patterson } \\
\text { et al. } \\
\text { (2005) }\end{array}$ \\
\hline $\begin{array}{l}\text { Supervisory support: alpha } \\
\text { (3.76; 1.03) }\end{array}$ & $\mathbf{0 . 8 4}$ & $\mathbf{0 . 8 8 *}$ \\
\hline $\begin{array}{l}\text { Supervisors can be relied upon to give good guidance to people. (3.59; } \\
\text { 1.04) }\end{array}$ & 0.878 & 0.868 \\
\hline $\begin{array}{l}\text { Supervisors show an understanding of the people who work for them. } \\
\text { (3.72; 0.99) }\end{array}$ & 0.864 & 0.851 \\
\hline
\end{tabular}

\begin{tabular}{|l|c|c|}
\hline Clarity of organisational goals: alpha & $\mathbf{0 . 6 9}$ & $\mathbf{0 . 8 7 ^ { * }}$ \\
\hline $\begin{array}{l}\text { People have a good understanding of what the organization is trying to } \\
\text { do. }(3.90 ; 1.01)\end{array}$ & 0.875 & 0.664 \\
\hline $\begin{array}{l}\text { Everyone who works here is well aware of the long-term plans and } \\
\text { direction of this company. (3.57; 1.19) }\end{array}$ & 0.875 & 0.842 \\
\hline
\end{tabular}

Both scales are taken from the Organisational Climate Questionnaire by Patterson et al. (2005) and are measured on a five-point Likert scale. ${ }^{*}$ Refers to the original full scale with five items each. 
Table 4: Perceived fairness/justice measures

\begin{tabular}{|l|l|c|}
\hline Construct & Item & $\begin{array}{c}\text { Mean (std. dev.) / } \\
\text { Cronbach's alpha }\end{array}$ \\
\hline $\begin{array}{l}\text { Distributive } \\
\text { justice }\end{array}$ & I believe that I am being rewarded fairly at work. & $3.50(1.16)$ \\
\hline $\begin{array}{l}\text { Procedural } \\
\text { justice }\end{array}$ & The rules and procedures to make decisions are fair. & $3.46(1.0)$ \\
\hline $\begin{array}{l}\text { Interactional } \\
\text { justice }\end{array}$ & The way my supervisor treats me is fair. & $3.97(0.96)$ \\
\hline Overall fairness: alpha & $\mathbf{0 . 6 5}$ \\
\hline
\end{tabular}

The items are taken from the justice scales by Kim and Leung (2007), each measured on a five-point Likert scale. 
Table 5: Work-family and family-work conflict

\begin{tabular}{|l|c|}
\hline \multicolumn{1}{|c|}{ Items (mean; std. dev.) } & $\begin{array}{c}\text { Cronbach's alpha/ } \\
\text { Factor loadings }\end{array}$ \\
\hline Work-family conflict: alpha & $\mathbf{0 . 8 6}$ \\
\hline $\begin{array}{l}\text { The demands of my work interfere with my home and family life. (2.36; } \\
1.21 \text { ) }\end{array}$ & 0.883 \\
\hline $\begin{array}{l}\text { The amount of time my job takes up makes it difficult to fulfill family } \\
\text { responsibilities. (2.30; 1.22) }\end{array}$ & 0.901 \\
\hline $\begin{array}{l}\text { My job produces strain that makes it difficult to fulfill family duties. (2.42; } \\
1.21 \text { ) }\end{array}$ & 0.868 \\
\hline
\end{tabular}

\begin{tabular}{|l|c|}
\hline Family-work conflict: alpha & $\mathbf{0 . 7 0}$ \\
\hline $\begin{array}{l}\text { I have to put off doing things at work because of demands on my time at } \\
\text { home. }(1.65 ; 0.87)\end{array}$ & 0.782 \\
\hline $\begin{array}{l}\text { Things I want to do at work don't get done because of the demands of my } \\
\text { family or spouse/partner. }(1.39 ; 0.68)\end{array}$ & 0.838 \\
\hline $\begin{array}{l}\text { My home life interferes with my responsibilities at work such as getting to } \\
\text { work on time, accomplishing daily tasks, and working overtime. }(1.43 ; 0.81)\end{array}$ & 0.745 \\
\hline
\end{tabular}

The items are a selection of the 10-item scale developed in Netemeyer et al. (1996), each measured on a five point Likert scale. 
Table 6: Big Five Inventory short scale

\begin{tabular}{|l|c|c|}
\hline \multicolumn{1}{|c|}{ Items (mean; std. dev.) } & \multicolumn{2}{c|}{$\begin{array}{c}\text { Cronbach's alpha/ } \\
\text { Factor loadings }\end{array}$} \\
\hline I see myself as someone who... & LPP & SOEP \\
\hline Extraversion: alpha & $\mathbf{0 . 6 2}$ & $\mathbf{0 . 6 9}$ \\
\hline is communicative, talkative. (4.16; .87) & 0.655 & 0.728 \\
\hline is outgoing, sociable. (3.93; .90) & 0.688 & 0.737 \\
\hline is reserved (R). (3.05; 1.14) & 0.784 & 0.795 \\
\hline
\end{tabular}

\begin{tabular}{|l|c|c|}
\hline Conscientiousness: alpha & $\mathbf{0 . 5 8}$ & $\mathbf{0 . 5 9}$ \\
\hline does a thorough job. $(4.51 ; .59)$ & 0.791 & 0.820 \\
\hline tends to be lazy (R). $(4.38 ; .79)$ & 0.631 & 0.638 \\
\hline does things effectively and efficiently. $(4.24 ; .59)$ & 0.741 & 0.731 \\
\hline
\end{tabular}

\begin{tabular}{|l|c|c|}
\hline Neuroticism: alpha & $\mathbf{0 . 5 6}$ & $\mathbf{0 . 6 1}$ \\
\hline worries a lot. (3.34; 1.14) & 0.649 & 0.763 \\
\hline gets nervous easily. (2.52; 1.11) & 0.800 & 0.796 \\
\hline is relaxed, handles stress well (R). (2.33; .92) & 0.680 & 0.637 \\
\hline
\end{tabular}

\begin{tabular}{|l|c|c|}
\hline Agreeableness: alpha & $\mathbf{0 . 4 7}$ & $\mathbf{0 . 5 3}$ \\
\hline is sometimes somewhat rude to others. (R) $(3.74 ; 1.12)$ & 0.818 & 0.782 \\
\hline has a forgiving nature. $(4.21 ; .73)$ & 0.414 & 0.568 \\
\hline is considerate and kind to others. $(4.25 ; .64)$ & 0.542 & 0.750 \\
\hline
\end{tabular}

\begin{tabular}{|l|c|c|}
\hline Openness to Experience: alpha & $\mathbf{0 . 5 5}$ & $\mathbf{0 . 6 5}$ \\
\hline is original, comes up with new ideas. $(3.71 ; .87)$ & 0.498 & 0.623 \\
\hline values artistic, aesthetic experiences. $(3.25 ; 1.17)$ & 0.751 & 0.635 \\
\hline has an active imagination. $(3.58 ; 1.02)$ & 0.719 & 0.687 \\
\hline is eager for knowledge. (4.11; .82) & 0.469 & 0.678 \\
\hline
\end{tabular}

The scales are taken from the Big Five Inventory short scale BFI-S, measured on a five-point Likert scale. 
Table 7: Risk attitudes and trust

\begin{tabular}{|l|l|c|c|}
\hline Construct & Item & \multicolumn{2}{|c|}{$\begin{array}{c}\text { Mean } \\
\text { (std. dev.) }\end{array}$} \\
\hline \multirow{2}{*}{ Risk } & Are you generally a person who is fully prepared to take & 5.7 & 5.1 \\
& risks or do you try to avoid taking risks? & $(1.84)$ & $(2.13)$ \\
\hline Trust & Nowadays one can't rely on anyone. & 3.29 & 2.64 \\
& & $(1.10)$ & $(0.74)$ \\
\hline Trust & On the whole one can trust people. & 3.61 & 2.40 \\
& & $(0.84)$ & $(0.65)$ \\
\hline
\end{tabular}

The items are taken from the German Socio Economic Panel Study. Risk is measured on a 11-point Likert scale and trust on a five-point Likert scale. 
Table 8: Justice sensitivity

\begin{tabular}{|l|l|c|}
\hline Construct & Item & $\begin{array}{c}\text { Mean (std. } \\
\text { dev.) / } \\
\text { Cronbach's } \\
\text { alpha }\end{array}$ \\
\hline Victim sensitivity & $\begin{array}{l}\text { It makes me angry when others are undeservingly better off } \\
\text { than me. }\end{array}$ & 2.68 (1.30) \\
\hline Beneficiary sensitivity & I feel guilty when I am better off than others for no reason. & 2.36 (1.17) \\
\hline Overall: alpha & \multicolumn{1}{|l}{0.56} \\
\hline
\end{tabular}

The items are taken from the USS-8 justice sensitivity inventory (Schmitt et al., 2010) and are measured on a five-point Likert scale. 
Table 9: Work engagement short scale

\begin{tabular}{|c|c|}
\hline Items (mean; std. dev.) & $\begin{array}{l}\text { Factor loadings / } \\
\text { Cronbach's alpha }\end{array}$ \\
\hline & LPP \\
\hline Dimension Vigour: alpha & 0.71 \\
\hline At my work, I feel bursting with energy. $(3.48 ; 0.99)$ & 0.623 \\
\hline At my job, I feel strong and vigorous. $(4.11 ; 0.83)$ & 0.658 \\
\hline $\begin{array}{l}\text { When I get up in the morning, I feel like going to work. } \\
(3.59 ; 1.16)\end{array}$ & 0.786 \\
\hline Dimension Dedication: alpha & 0.82 \\
\hline I am enthusiastic about my job. $(3.84 ; 1.01)$ & 0.830 \\
\hline My job inspires me. $(3.48 ; 1.25)$ & 0.787 \\
\hline I am proud on the work that I do. $(4.17 ; 0.97)$ & 0.775 \\
\hline Dimension Absorption: alpha & 0.84 \\
\hline I feel happy when I am working intensely. (3.96; 1.02) & 0.738 \\
\hline I am immersed in my work. $(3.73 ; 1.12)$ & 0.831 \\
\hline I get carried away when I'm working. (3.59; 1.13) & 0.852 \\
\hline Overall: alpha & 0.91 \\
\hline
\end{tabular}

The items are taken from the Utrecht Work Engagement Short Scale (Schaufeli and Bakker, 2004) and are measured on a five-point Likert scale. 
Table 10: Items and factor loadings of affective commitment

\begin{tabular}{|l|c|c|}
\hline Items (mean; std. dev.) & \multicolumn{2}{|c|}{$\begin{array}{c}\text { Factor loadings / } \\
\text { Cronbach's alpha }\end{array}$} \\
\hline & $\begin{array}{c}\text { Meyer et } \\
\text { al. (1993) }\end{array}$ \\
\hline $\begin{array}{l}\text { I would be very happy to spend the rest of my career with this organization. } \\
\text { (4.05; 1.18) }\end{array}$ & 0.679 & 0.645 \\
\hline This organization has a great deal of personal meaning for me. (3.83; 1.17) & 0.786 & 0.749 \\
\hline I really feel as if this organization's problems are my own. (2.98; 1.32) & 0.638 & 0.410 \\
\hline $\begin{array}{l}\text { I do not feel a strong sense of "belonging" to my organization. (R) (3.89: } \\
\text { 1.21) }\end{array}$ & 0.784 & 0.735 \\
\hline I do not feel "emotionally attached" to this organization. (R) (3.82; 1.21) & 0.792 & 0.680 \\
\hline I do not feel like "part of the family" at my organization. (R) (3.80; 1.22) & 0.719 & 0.735 \\
\hline Overall: alpha & $\mathbf{0 . 8 3}$ & $\mathbf{0 . 8 2}$ \\
\hline
\end{tabular}

The items are taken from the affective commitment short scale by Meyer et al. (1993) measured on a five-point Likert scale. 
Table 11: Items and factor loadings of WHO-5

\begin{tabular}{|l|c|}
\hline \multicolumn{1}{|c|}{ Items (mean; std. dev.) } & $\begin{array}{c}\text { Factor loadings / } \\
\text { Cronbach's alpha }\end{array}$ \\
\hline I have felt cheerful and in good spirits. $(2.59 ; 1.21)$ & 0.834 \\
\hline I have felt calm and relaxed. $(2.75 ; 1.29)$ & 0.832 \\
\hline I have felt active and vigorous. (3.06; 1.34) & 0.749 \\
\hline I woke up feeling fresh and rested. (3.14; 1.44) & 0.776 \\
\hline My daily life has been filled with things that interest me. $(2.81 ; 1.27)$ & 0.722 \\
\hline Overall: alpha & $\mathbf{0 . 8 4}$ \\
\hline
\end{tabular}

The items are taken from the WHO-5-Well-Being Questionnaire (Bech et al., 2003 and https://www.psykiatriregionh.dk/who-5/who-5-questionnaires/Pages/default.aspx) and are measured on a six-point scale. 
Table 12: Mean and standard deviation of the satisfaction measures

\begin{tabular}{|l|l|c|c|}
\hline Construct & Item & \multicolumn{2}{|c|}{ Mean (std. dev.) } \\
\hline & & LPP & SOEP \\
\hline Job satisfaction & How satisfied are you with your job? & $7.56(1.75)$ & $7.00(1.97)$ \\
\hline Income Satisfaction & How satisfied are you with your income? & $6.67(2.17)$ & $6.62(2.13)$ \\
\hline
\end{tabular}

The items are taken from the German Socio Economic Panel Study and measured on a 11-point scale. 
Table 13: Behavioural variables

\begin{tabular}{|l|l|l|}
\hline Construct & Item & Mean (std. dev.) \\
\hline Intention & $\begin{array}{l}\text { How many times in the past 12 months have you thought } \\
\text { about changing your job? }\end{array}$ & $1.61(0.93)$ \\
\hline $\begin{array}{l}\text { Sickness } \\
\text { absence }\end{array}$ & $\begin{array}{l}\text { How many days were you unable to work due to illness in } \\
\text { the past } 12 \text { months? Please state the total number of days, } \\
\text { not just the number of days for which you had an official } \\
\text { note from your doctor. }\end{array}$ & \\
\hline
\end{tabular}

The turnover intention item is measured following Bluedorn (1982), measured on a five-point scale and the sickness absence item is taken from the SOEP. 


\section{Appendix}

Table A1: Pearson pairwise correlations among variables

\begin{tabular}{|c|c|c|c|c|c|c|c|c|c|c|c|}
\hline & Variable & Mean & SD & 1 & 2 & 3 & 4 & 5 & 6 & 7 & 8 \\
\hline 1 & $\begin{array}{l}\text { Affective } \\
\text { Commitment }\end{array}$ & 3.73 & 0.89 & & & & & & & & \\
\hline 2 & Work Engagement & 3.77 & 0.80 & $.50 * *$ & & & & & & & \\
\hline 3 & Job satisfaction $^{a}$ & 7.56 & 1.75 & $.50 * *$ & $.51^{* *}$ & & & & & & \\
\hline 4 & Risk attitude ${ }^{a}$ & 5.74 & 1.84 & $.04^{*}$ & $.15^{* *}$ & $.11^{* *}$ & & & & & \\
\hline 5 & Trust & 3.45 & 0.79 & $.23 * *$ & $.16^{* *}$ & $.22 * *$ & $.05 * *$ & & & & \\
\hline 6 & $\begin{array}{l}\text { Clarity of } \\
\text { organizational goals }\end{array}$ & 3.73 & 0.96 & $.35^{* *}$ & $.30 * *$ & $.35^{* *}$ & $.06 * *$ & $.15^{* *}$ & & & \\
\hline 7 & Supervisory support & 3.69 & 0.89 & $.41 * *$ & $.40 * *$ & $.49 * *$ & $.06 * *$ & $.21 * *$ & $.50 * *$ & & \\
\hline 8 & Fairness & 3.64 & 0.80 & $.46^{* *}$ & $.38 * *$ & $.52 * *$ & $.02 *$ & $.26 * *$ & $.42 * *$ & $.57^{* *}$ & \\
\hline 9 & Turnover intention $^{\mathrm{b}}$ & 1.61 & 0.93 & $-.50 * *$ & $-.35 * *$ & $-.52 * *$ & -.004 & $-.18^{* *}$ & $-.30 * *$ & $-.37 * *$ & $-.47^{* *}$ \\
\hline 10 & Extraversion & 3.71 & 0.73 & $.11^{* *}$ & $.21^{* *}$ & $.13^{* *}$ & $.20 * *$ & $.06 * *$ & $.12^{* *}$ & $.11^{* *}$ & $.09 * *$ \\
\hline 11 & Conscientiousness & 4.38 & 0.48 & $.10^{* *}$ & $.27^{* *}$ & $.14^{* *}$ & $.06 * *$ & $-.05^{* *}$ & $.16^{* *}$ & $.14^{* *}$ & $.09 * *$ \\
\hline 12 & Neuroticism & 2.73 & 0.77 & $-.08 * *$ & $-.16 * *$ & $-.21 * *$ & $-.15^{* *}$ & $-.19 * *$ & $-.11^{* *}$ & $-.14^{* *}$ & $-.18^{* *}$ \\
\hline 13 & $\begin{array}{l}\text { Openness to } \\
\text { experience }\end{array}$ & 3.67 & 0.63 & $.11^{* *}$ & $.24 * *$ & $.08 * *$ & $.22 * *$ & $.05^{* *}$ & $.10 * *$ & $.09 * *$ & $.05 * *$ \\
\hline 14 & Agreeableness & 4.07 & 0.58 & $.10 * *$ & $.17^{* *}$ & $.13^{* *}$ & $-.03 * *$ & $.13 * *$ & $.14 * *$ & $.18^{* *}$ & $.14^{* *}$ \\
\hline 15 & Absenteeism ${ }^{c}$ & 11.6 & 24.3 & $-.09 * *$ & $-.08 * *$ & $-.14 * *$ & $-.03 * *$ & $-.08 * *$ & -.02 & $-.06 * *$ & $-.10 * *$ \\
\hline 16 & Income satisfaction & 6.67 & 2.17 & $.39 * *$ & $.28 * *$ & $.44^{* *}$ & $.03 *$ & $.23 * *$ & $.25^{* *}$ & $.30 * *$ & $.62 * *$ \\
\hline 17 & Work-family conflict & 2.36 & 1.07 & $-.19 * *$ & $-.20 * *$ & $-.32 * *$ & .01 & $-.17^{* *}$ & $-.19 * *$ & $-.30 * *$ & $-.30 * *$ \\
\hline 18 & Family-work conflict & 1.49 & 0.62 & $-.13 * *$ & $-.10 * *$ & $-.16^{* *}$ & $.03 * *$ & $-.12^{* *}$ & $-.11^{* *}$ & $-.12 * *$ & $-.15^{* *}$ \\
\hline 19 & $\begin{array}{l}\text { Employee well- } \\
\text { being }\end{array}$ & 4.13 & 1.02 & $.22^{* *}$ & $.40 * *$ & $.34 * *$ & $.15^{* *}$ & $.19 * *$ & $.20^{* *}$ & $.25^{* *}$ & $.27^{* *}$ \\
\hline 20 & Justice sensitivity & 2.52 & 1.03 & $-.07 * *$ & $-.05 * *$ & $-.11 * *$ & -.01 & $-.11 * *$ & $-.03 * *$ & $-.05 * *$ & $-.14^{* *}$ \\
\hline
\end{tabular}

\begin{tabular}{|c|c|c|c|c|c|c|c|c|c|c|c|c|}
\hline & Variable & 9 & 10 & 11 & 12 & 13 & 14 & 15 & 16 & 17 & 18 & 19 \\
\hline 10 & Extraversion & $-.04 * *$ & & & & & & & & & & \\
\hline 11 & $\begin{array}{l}\text { Conscientiou } \\
\text { sness }\end{array}$ & $-.06 * *$ & $.26^{* *}$ & & & & & & & & & \\
\hline 12 & Neuroticism & $.15^{* *}$ & $-.17^{* *}$ & $-.08 * *$ & & & & & & & & \\
\hline 13 & $\begin{array}{l}\text { Openness to } \\
\text { experience }\end{array}$ & $.04 * *$ & $.33 * *$ & $.25 * *$ & $-.03 * *$ & & & & & & & \\
\hline 14 & $\begin{array}{l}\text { Agree- } \\
\text { ableness }\end{array}$ & $-.09 * *$ & $.10 * *$ & $.30 * *$ & $-.13^{* *}$ & $.15^{* *}$ & & & & & & \\
\hline 15 & Absenteeismc & $.08 * *$ & .01 & .02 & $.11^{* *}$ & .02 & .01 & & & & & \\
\hline 16 & $\begin{array}{l}\text { Income } \\
\text { satisfaction } \\
\text { a }\end{array}$ & $-.40 * *$ & $.03 * *$ & -.01 & $-.13^{* *}$ & -.002 & $.04 * *$ & $-.11^{* *}$ & & & & \\
\hline 17 & $\begin{array}{l}\text { Work-family } \\
\text { conflict }\end{array}$ & $.32 * *$ & $-.04 * *$ & $-.06 * *$ & $.20^{* *}$ & .02 & $-.13^{* *}$ & $.07^{* *}$ & $-.21^{* *}$ & & & \\
\hline 18 & $\begin{array}{l}\text { Family-work } \\
\text { conflict }\end{array}$ & $.16^{* *}$ & $-.07 * *$ & $-.15^{* *}$ & $.12^{* *}$ & -.01 & $-.13^{* *}$ & .02 & -.10 & $.37 * *$ & & \\
\hline 19 & $\begin{array}{l}\text { Employee } \\
\text { well-being d }\end{array}$ & $-.24 * *$ & $.19^{* *}$ & $.14^{* *}$ & $-.30 * *$ & $.17^{* *}$ & $.13^{* *}$ & $-.17^{* *}$ & $.19^{* *}$ & $-.24 * *$ & $-.11^{* *}$ & \\
\hline 20 & $\begin{array}{l}\text { Justice } \\
\text { sensitivity }\end{array}$ & $.10^{* *}$ & $-.05^{* *}$ & $-.04 * *$ & $.20 * *$ & .004 & $-.07 * *$ & .01 & $-.14 * *$ & $.11^{* *}$ & $.12^{* *}$ & $-.09 * *$ \\
\hline
\end{tabular}

Note. $n$ ranges from 7,087 to $7,501 .{ }^{*} p<.05,{ }^{* *} p<.01$. All items range from 1 to 5 except those with ${ }^{a}$ ranging from 0 to $10,{ }^{b}$ Reverse coded: answer categories here range from 1 (never) to 5 (every day), ${ }^{c}$ counting the number of sick days, ${ }^{d}$ ranging from 1 to 6 . Source: LPP employee survey 2012. 
[1] This paper focuses on the first cross section of the LPP. The second survey wave is being conducted in $2014 / 2015$ and a third is planned for 2016/2017.

[2] A detailed description of the sampling is available in the method report by Bellmann et al. (2015) and a detailed description of all variables by Broszeit and Wolter (2015) Both LPP questionnaires and additional information can be downloaded from http://fdz.iab.de/en/Integrated_Establishment_and_Individual_Data/Ipp.aspx.

[3] The questionnaire made sure that the respondents still worked in the participating establishment.

[4] The Establishment History Panel is an administrative data source based on employers' reports to social security authorities. The data is available from 1975 or, if a firm was founded later, from this time point on. [5] A detailed description of the variables is provided in Fischer et al. (2009).

[6] Each scale contains three to six single questions. The items are: autonomy regarding decision making, work scheduling and work methods, task variety, task significance, task identity, and feedback from job (task characteristics); job complexity, information processing, problem solving, skill variety, and specialization (knowledge characteristics); social support, initiated and received interdependence, interaction outside organization and feedback from others (social characteristics); physical demands, ergonomics, work conditions, and equipment use (work context).

[7] The social security records report earnings up to the social security contribution threshold and include every payment subjected to social security.

[8] To make both data sets comparable, we restrict the SOEP sample to regular employees working in private sector establishments with at least 20 employees (50 employees are not available as single category) excluding the primary sector.

[9] Mauno et al. (2007) note that absorption shares some conceptual similarities to the concept of flow experience, vigor to intrinsic motivation and dedication to job involvement.

[10] Continuance commitment refers to employees' profit associated with continued participation and costs associated with leaving the organization and normative commitment to employees' feelings of obligation to remain in the organization.

[11] The application forms are available at http://fdz.iab.de/en/Integrated_Establishment_and_Individual_Data/Ipp/Data_Access.aspx.

[12] An exception is the British Workplace Employment Relations Study (WERS). However, it is not possible to link individual data from WERS to other individual-level data sources such as administrative data, as possible in the LPP. Furthermore, no information is elicited in the WERS survey of employees on, for instance, personality traits or scales such as commitment and engagement. 